\title{
Transformation of Consumption Behavior of the Poor in the Case of Malnutrition: Health Sociology Study with Participatory Approach in Makassar City, Indonesia
}

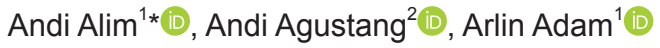 \\ ${ }^{1}$ Department of Public Health, University of Pejuang Republic Indonesia, Makassar, South Sulawesi, Indonesia; ${ }^{2}$ Department \\ of Sociology, University of State Makassar, Makassar, South Sulawesi, Indonesia
}

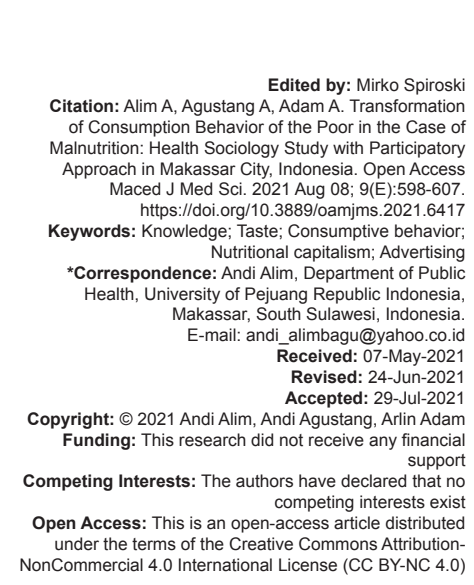

Abstract

BACKGROUND: Poor families understand, interpret, and interpret the balanced nutritional content of food and beverages consumed daily differently according to their experiences and the environment they encounter. The assumption of this research assumes that there is a change in consumer behavior due to the knowledge of the poor which is formed by advertisements with very high exposure and frequency every day.

AIM: This study aims to explore the consumption behavior that causes the process of malnutrition and how the framework of capitalism marginalizing the poor to meet their nutritional needs.

METHODS: This study uses qualitative research methods through a critical approach. The basic assumption of this paradigm is that all knowledge is generated on the motives of the interests of the dominant group.

RESULTS: This study resulted in the findings of malnutrition in the poor in Makassar City due to erroneous public knowledge in understanding nutritious food. Meanwhile, children's tastes are formed based on environmenta influences which are generally constructed by industrially processed foods. Another finding is that the framework of capitalism in marginalizing the poor in fulfilling their nutritional needs operates in the form of massification of industrially processed food and beverage products; the intensity of advertisements for nutritious food products, the presence of online food ordering technology; construction of the lifestyle of the haves; and the emergence of outlets or shops serving fast food.

CONCLUSIONS: The critical paradigm used in this research produces sociological actions that need to be taken to avoid the trap of food capitalism for poor families through the community empowerment movement toward shopping behavior for healthy consumption.

\section{Introduction}

Several scientific studies on the phenomenon of malnutrition have been carried out by various people including Moniharapon, et al. (1999) regarding the analysis of advertising claims and labels on food products showing that $9.8 \%$ of food advertisements are advertisements for milk and its processed products. Based on the results of the analysis, five leading formula milk brands have excessive claims. The advertisement claim for formula milk is considered excessive because it creates an impression in the minds of consumers that good growth and development of children can be achieved only by consuming the milk [1].

Another study was presented by Hidayat et al. (2009) in their research on mothers' perceptions and attitudes toward nutritional claims in advertisements for advanced formula milk for preschoolers and their relationship to purchasing decisions. Based on the results of the analysis conducted, it was found that there was a significant positive relationship between income and perception. In addition, perceptions and attitudes toward brand nutritional claims were significantly related to the length of use of milk brands $(p<0.05)$ [2].

The results of research with different perspectives but in the same context were also stated by Sabriyan, (2013) in Dode Lojirejo Hamlet showing that there is a positive and significant correlation both individually and jointly between perceptions of formula milk advertisements on television and nutritional knowledge. Mothers with mothers' actions in giving formula milk to toddlers aged $0-2$ years in Dode Lojirejo Hamlet [3].

The studies above have the same problem in photographing the phenomenon of malnutrition. This study also aims to dissect the problem of malnutrition but has a different epistemology. All the previous studies used positivistic epistemology, while this study used critical epistemology. Although advertising is placed as a determinant variable in influencing consumer behavior in choosing nutritional products, this study views advertising in a more fundamental discourse where advertising is used as a means of 
communication for the dominant group to form false awareness among the poor. In this context, the type of argumentation regarding advertising is different from the previous studies.

Nationally, the prevalence of underweight in 2013 was $19.6 \%$, consisting of $5.7 \%$ of malnutrition, and $13.9 \%$ of undernourished. When compared with the national prevalence rate in 2007 (18.4\%) and $2010(17.9 \%)$, it seems to increase. Changes, especially in the prevalence of malnutrition, were from $5.4 \%$ in $2007,4.9 \%$ in 2010 , and $5.7 \%$ in 2013 . Meanwhile, the prevalence of malnutrition increased by $0.9 \%$ between 2007 and 2013. To achieve the target, the 2015 MDGs were $15.5 \%$, the prevalence of malnutrition nationally should be reduced by $4.1 \%$ in the period 2013 to 2015 [4].

In South Sulawesi Province, the prevalence of malnutrition and undernutrition from year to year is increasing as illustrated in the Basic Health Research data starting in 2007, 2010, and 2013, namely, in 2007 cases of malnutrition and malnutrition were $17.6 \%$, in $2007-2010$ as many as $25 \%$ while in 2013 there were cases as many as $25.60 \%$. In Makassar City, the prevalence of cases of malnutrition and malnutrition is $28.1 \%$; this figure is above the provincial figure of $25.60 \%$ and the national figure of $19.6 \%$ [4], [5], [6].

The above statistics are contributed more by the poor population because they generally do not have the purchasing ability to access products that have nutritional value while, on the one hand, they already have a high appetite following the tastes of the class society. The formation of tastes is the result of the construction of nutrition advertisements that are widely displayed through various media. This phenomenon is similar to Foucault's analysis in looking at the mechanism of power through knowledge and discourse. The poor seem to have no power to make decisions in buying food products because knowledge and discourse have been produced and led by capitalists who seem to force people to obey them.

In Foucauldian thought, power is determined by knowledge and discourse. Between the three aspects that makeup the social relations occur dialectically. Behind knowledge there is power, and vice versa, power contains elements of knowledge. Meanwhile, knowledge is formed on discourse or discourse forms knowledge. For Foucault, discourse or dominant knowledge is called episteme. This episteme is then formed by the effective mediation of advertising exposure.

The influence of advertising at its peak disciplines all individual actions that lead to the formation of a consumptive lifestyle. People who experience a downturn due to the construction of a consumptive lifestyle are poor because the resources they have are unable to facilitate new needs that are deliberately created by the capitalists. This is what explains the phenomenon of poor people who are malnourished because they make wrong decisions about balanced nutrition. It is as if nutritionally balanced food must be produced by industry, branded, well packaged, and purchased in sales windows.

Thus, developing knowledge can be used among the poor in understanding, interpreting, and interpreting the concepts of healthy living with nutrition. In the assumption of this study, the knowledge of the poor does not arise naturally but is systematically shaped by advertisements whose exposure and frequency are almost daily and under any circumstances. If the logic above is used, it is natural that poor people are always in a state of malnutrition. Ironically, malnutrition of poor families produces new problems such as inability to access education, inability to access economics, and experiencing injustice in social relations which leads to underdevelopment.

Toddlers belonging to poor families are seriously affected by family mistakes in choosing unbalanced food due to exposure to advertisements that tend to be misleading. Family tastes are only concerned with the symbolic value of food has ruled out the nutritional value that is very useful for the growth and development of children. In this condition, children do get their consumption needs, but children do not get adequate nutrition. Toddlers who do not get adequate nutrition will experience various impacts of social problems such as decreased learning/thinking abilities; decreased growth, physical ability and resilience of vulnerable bodies; and threats of malnutrition and disease.

The nutritional intake of school children is still very concerning. Even though good nutrition intake is needed every day to have good intellectual abilities so that they become the next generation of a superior nation. Malnutrition at the age of toddlers can affect mental development and thinking skills. Because the brain organ reaches, its maximum shape at the age of 2 years. Lack of nutrition can result in permanent disruption of brain function. Therefore, the ability of children to learn or children's achievement in school decreases. School-age children are the nation's investment because they are the nation's next generation. Hence, it is our obligation as parents to always pay attention to the quality and quantity of children's nutritional intake. The quality of the nation in the future is determined by the children of today.

In general, many families still do not care about the nutritional content consumed by their children. They are more concerned that "the important thing is that the child is full", without paying attention to the nutritional balance. In fact, as a result of poor nutritional intake, the body's resistance to pressure or stress decreases. The immune system and antibodies are reduced, making them susceptible to infections such as colds, coughs, and diarrhea. In children, this can be dangerous and can even lead to death. The optimal 
growth and development of school-age children also depend on the provision of good and correct nutrition with good quality and quantity. During this period of growth and development, the provision of nutrition or food intake to children cannot always be carried out perfectly so that the impact of nutritional problems for school children can be in the form of impaired growth and low physical fitness. Therefore, the growth and development of children must be considered as early as possible, to avoid the threat of various diseases that can lead to death. One example that can be taken cases in endemic areas of lodine Deficiency Disorders, resulting in severely stunted population growth such as midgets or cretinism.

Lack of a balanced intake of nutrients in the long term can lead to the threat of malnutrition even starting during pregnancy or in the mother's womb. Malnutrition can cause death if not treated as early as possible. In addition to malnutrition, there is a threat of other diseases caused by school children's food or snacks. Snacks that contain chemicals and are carcinogenic, such as preservatives (formalin, borax), synthetic dyes, flavorings (MSG) can accumulate in the body which in the long run causes cancer and tumors. If children consume an unbalanced nutritional intake, then the threat is in the form of diseases such as iron deficiency anemia, vitamin A deficiency, and even disorders due to iodine deficiency in a community, especially endemic areas.

The end of all the consequences of malnutrition is the incidence of death in children, especially children under five, which demographically will affect the structure and dynamics of the population, including the projection of the occurrence of losing generation symptoms. The complexity of the problem allows alternative thinking in changing the situation and social status of the poor, especially in fulfilling their nutrition. Alternative thinking that must be raised must be in the form of the antithesis of established thoughts or approaches.

Therefore, this study uses a critical approach to raise critical awareness of the poor about the actual conditions and seek to take actions based on their potential. Practically, the method used in producing the intended change is the empowerment method which is applied in a participatory manner. The critical approach is not only applied methodologically but this approach is also used theoretically. The theories used as surgical instruments are theories that are epistemologically included in the critical tradition, including the theory of discourse, knowledge, and power put forward by Micael Foucault, the theory of hyperreality by Baudrillard, the concept of false consciousness from Marx, and several theories- theory-oriented to community empowerment as an alternative theoretical solution to this research.

Based on the above background, this study aims to explore the transformation of consumer behavior that causes the process of malnutrition by conducting field observations and in-depth interviews which further develops theoretical solutions in achieving local awareness in the poor through research questionnaires.

\section{Methods}

\section{Type and research design}

This study used qualitative research methods. This method was chosen as a consequence of the paradigmatic view of research that uses a critical paradigm. The research design using grounded research techniques seeks to explore in-depth the phenomenon of malnutrition experienced by poor families using dialogical communication between researchers and poor families.

\section{Research sites}

This research was conducted in Makassar City because it has the largest prevalence of malnutrition when compared to the figures for South Sulawesi Province and the national figure. Based on the subdistrict level, Tamalate District is the location of the study as a representative of Makassar City because it has the largest number of malnutrition cases.

\section{Data source}

Sources of data in this study consisted of primary data and secondary data. Primary data were obtained using interview guidelines with the main question now is the community's knowledge of the incidence of malnutrition? How are the tastes of the poor in choosing food? How does capitalism encourage the consumptive behavior of the poor? What is the role of advertising in constructing consumption behaviou? While secondary data obtained in the form of written and unwritten information has to do with this research. Secondary data in this study are data obtained from government agencies such as the Central Statistics Agency, Makassar City Government, Health Office, Hospitals and Health Centers, as well as other documents that support this research.

\section{Research focus}

The focus of this research is the causes of the transformation of the consumption behavior of the poor; Capitalism framework that changes eating behavior includes a consumptive lifestyle, nutritional capitalism, and advertising. 


\section{Data collection technique}

Data collection was carried out by observation, in-depth interviews, and Focus Group Discussion (FGD). Observations were made on groups of cases systematically based on the formulated objectives of the investigation. In-depth interviews were conducted using the question guide tool. For the interview process to be inseparable from the context of the events that underlie it, the researchers used field notes which were supported by electronic tools in the form of cameras and recorders. FGD was conducted to analyze the tendency of differences or similarities in information on a phenomenon, especially to reconfirm the questions given in the in-depth interview technique [7].

\section{Research objectives and criteria}

The target of this study is poor families who experience malnutrition. The method of withdrawing research informants was carried out by using purposive sampling technique with the following criteria: Recipients of the Program of Hope Family, having malnourished children, willing to be interviewed, having initial knowledge by the problems studied, adult age, and concerned physically and mentally healthy. The number of research informants as many as 9 people was determined based on the consideration of the level of saturation of the information needed.

\section{Data analysis}

Qualitative data analysis uses data analysis while collecting data (analysis in the field) by exploring in-depth the contents of the questions given by the informants. In general, the stages of qualitative data analysis are in three stages of the process; (1) data reduction, (2) data categorization, and (3) data interpretation.

\section{Presentation of data}

The presentation of qualitative data is carried out by exploring in-depth the patterns of relationships between the data and presenting data displays in the form of quotations from informants so that the data exploration becomes stronger (powerful) and full of meaning (meaningful).

\section{Research instruments}

The main instrument of this research is the researcher himself who will explore each phenomenon with the help and support of other instruments in the form of interview guides for in-depth interviews, discussion guides for FGDs, and observation sheets.

\section{Results}

\section{Behavior transformation}

Knowledge

Below are excerpts from the core interviews regarding knowledge:

"I don't understand that, sir. Does the noodle have nutrition or not. But why is it allowed by the government if it's not good to eat?" (Bau, Barombong, 2019).

"The money is for shopping for basic needs and food ingredients. Sometimes I eat fish, sometimes eggs or just noodles". (Kamariah, Tanjung Mardeka, 2019).

"I am a person who likes to snack, most like to eat meatballs. The children also have snacks. If there is a travelling salesman, the children will beg to be bought. If you are full, you will be lazy to eat rice. I'm often lazy to cook, mostly just for my husband. Fortunately, my husband is not too dizzy when it comes to food. Often when I cook, no one eats because they are full of snacks". (Lina, Maccini Sombala, 2019).

"As far as I know nutrition is expensive. Even though it's cheap, we must know how to process it. The short child, he said, is called stunting because the child is malnourished. No wonder western people are big because they are nutritious". (Juha, Parangtambung, 2019). "I know that fruits like mangoes are nutritious, that's why I always eat them with my family. From his father's village, he was always down with all kinds of mangoes, bananas. He said a lot of vitamins. We are sickly because we lack fruit". (Kaminang, Mangasa, 2019).

The low level of knowledge so that mothers do not pay much attention to the menu of dishes to be cooked. It's just set up modestly, the important thing is to eat with rice and side dishes, that's enough. Mothers are not too dizzy in managing their daily diet, because they consider nutrition as something expensive. Rarely eat vegetables and fruits, and give milk to toddlers for expensive reasons. Lack of knowledge has an effect on the emergence of more frequent snacking behaviors that affect the family's irregular eating patterns. Family knowledge also affects the selection of food menus that do not take into account the balance of nutritional values. Informants consider that eating is an indicator that it is delicious and filling.

The family's diet is also shaped by the availability of food sources originating from their hometowns, which are generally in the form of fruits. Informants understand that village food is healthy and contains many nutrients. Because of the type of fruit that is most often obtained from the village, the family's diet is dominantly consuming fruits without regard to aspects of nutritional balance. 
The nutritional value of food for informants is not important. For him, the availability of food in the market has received permission from the government and is something good for the community. Some informants think that "Indomie" food tends to be the main menu choice for families because apart from being easy to reach, it is also economical. The value of food costs becomes the basis for making family decisions in choosing food, even though the informants have a good understanding of the benefits of food for body health, especially the growth and development of babies.

There is a tendency for income to have a more dominant role in determining food choices for the poor compared to the role of knowledge. This trend is especially strong for families with a large number of family members.

\section{Taste}

Below are excerpts from the core interview on

taste

"My child often eats sweet things to the point where it is difficult to give him rice. Finally skinny. The problem is that the seller is unavoidable. It has a big influence on the defending children". (Bau, Barombong, 2019).

"Because my son likes to eat chocolate and sweets, it makes it difficult to give him food. Several times the pack is done by playing so that his appetite is good. Sometimes the rice is decorated with decorations to provoke his appetite. But still lazy. In the end, noodles are low in weight". (Kamariah, Tanjung Mardeka, 2019). "On Eid day, children usually eat well. We do not limit to buy something because it's time sir. Let it be difficult but we as parents need to understand the needs of children. Pity his friend's kids drank Coca-Cola he just watched. His friend ate ice cream he just swallowed saliva. So the problem of appetite sometimes follows the children's wishes". (Sarifa, Balang Baru, 2019).

"When there is a family wedding party, usually when the children are 4 months old, I already give them formula milk. But not routinely because of difficult economic problems. But even though it is difficult if there is a married family, there are many people who gather. Family at gathering. We are also embarrassed if the children are given tea. Usually, the teat is filled with tea to help formula milk. So when we leave the house, we give formula milk. It's only once in a while". (Memang, Jongaya, 2019).

"The taste of the children depends on what l eat. If I eat corn he also eats corn. If you eat rice, so will Mr. My taste can't be forced because our economic capacity is limited. As it is. If there is more money, the children's food is even better. Even if the children cry asking to buy good food but there is no money, that's why I was a parent just let them cry. It's been quiet for a long time". (Lina, Maccini Sombala, 2019).

Chocolate and sugar form the main tastes of children's food for children of poor families so that it is difficult to take other foods so that their physical development becomes disturbed. Chocolate and confectionery are all industrial preparations that are easily available in almost all shops or outlets with affordable selling values in all circles. Easy to obtain, attractive packaging, good taste, and not expensive are factors that generally construct appetite for poor families as experienced by the informants.

The two types of food that is often chosen (chocolate and confectionery) contain a sweet taste that is easy to arouse appetite so that it becomes a habit. As a result, the appetite for eating sweet foods becomes a habit and even crystallizes into culture. In some cases, the taste for sweet foods also pretends to form a new lifestyle for families in choosing food ingredients for their families.

Sociologically, appetite is not always related to health factors, but rather to economic conditions, culture, and lifestyle. Symptoms of poverty that affect the formation of appetite, it seems through the process of habituation of eating patterns. Due to economic incapacity, the family only chooses certain types of food with a repeating pattern. This also means that the formation of tastes can be said to be due to compulsion.

The informants' tastes are also shaped by the activities of holding parties or socio-religious rituals such as the Birthday of the Great Prophet Subhanahu wata'ala. Again, the meaning emerges that nutritious food contains an expensive value and can only be served on certain occasions. For informants, serving food at parties is considered nutritious food because its presentation requires an expensive cost. This means that the taste is attached to the expensive value of the food. Consequently, the expensive value of food for informants has a welfare value which symbolically affects the social status of the family. This explains why families are embarrassed if they do not serve food with high economic value.

\section{Exposure to capitalism}

\section{Consumptive behavior}

Below are excerpts from the core interviews regarding consumptive behaviour

"It's hard to avoid the influence of the environment, sir. I always have to shop at the market now and then. Because if you haven't shopped for a long time at the neighboring market, you sometimes ask if he feeds his 
family. Even though we often buy fish". (Bau, Barombong, 2019).

"Sometimes it's not a need but we buy it, it doesn't mean a lot of money but that's how it is. For example, children's birthdays but we actually can't afford it. But the kids always tell stories about their friends whose birthdays we end up shopping for birthday food". (Kamariah, Tanjung Mardeka, 2019).

"Babies have also eaten SUN now, just provide water in a thermos with a dispenser. If we first have to cook porridge. Now don't bother". (Lina, Maccini Sombala, 2019).

"He said the pizza was like a dry cat vomit. I want to eat what it tastes like. It's expensive though. The children just go along with the westerners. I want to say". (Juha, Parangtambung, 2019).

Exposure to food capitalism still targets all people and not just people who are considered the haves. Exposure to unhealthy foods for the poor is available in other forms such as instant noodles, candy, snacks, roadside/mobile sales, and the like. In essence, the industrialization of food has led all circles of urban society to enjoy foods that contain flavor and color enhancers that create appeal or taste.

Buying decisions are not based on needs, but because of the desire to consume with various motives including wanting to be considered belonging, wanting to be categorized as a wealthy person, wanting to classify themselves the same as the "western" way of consuming, and satisfying psychological desires which are usually oriented towards hedonism or the nature of hedonism just having fun.

The transformation of eating patterns in urban poor families is not only determined by the presence of technology, but the role of imitating the "western" lifestyle seems to have a contribution such as a habit of consuming pizza. Pizza is a portion of American food that symbolizes progress, ability, greatness, prosperity, and various attributes that describe the traditions of American and European society that are often classified in the category of Western Life.

The role of capitalism is reflected by the statements of informants regarding the practical reasons for obtaining food. The existence of food industry technology has influenced the character of practicality among poor families. The ease with which food is obtained due to the presence of online food sales (start-ups) is the main means of forming eating habits. In general, fast food is offered as a menu in a start-up application. Thus, the exposure to fast food for poor families is very high which allows them to consume it quickly.

\section{Nutritional capitalism}

Below are excerpts from core interviews about nutritional capitalism
"I am also fifty-fifty. That height or something. Nothing is lost it's breast milk. If you think. Breast milk is necessary, but if there is no milk, we will help. Because instead of crying children. We'd better help, pity". (Sarifa, Balang Baru, 2019).

"That's milk. I mean, when we give milk to stop, he's bound to cry. So, I used to not have much milk. So I love to drink formula milk. Breastfeed first until 4 months, 3 months more. So after a while, it's like how. It's hard to feel sorry for sucking my nipples. So I love to drink formula milk". (Bau, Barombong, 2019).

"No. There is no nutrition for instant noodles. It's just what's in, it's okay. There are only vegetables, fruits which are clearly vegetables. Staple food, daily food". (Kadariah, Bongaya, 2019).

"Kids now just order food online. Whatever my nephew wants to eat, just order". (Kadariah, Bongaya, 2019).

"Cooked. Never bought something like eating it like that. No. We cook ourselves. If so, so am I. If drinks like glass tea are like that, what. All kinds of things. Like I want to. What is a lot of preservatives. If you say problems with drinks like glass tea, there are many preservatives. What. what colouring". (Hasna, Pa'baengbaeng, 2019).

Nutritional capitalism as found in the field is characterized in several situations including attractive food packaging, framing of nutritional content, online food offerings, the presence of food supplements in the form of preservatives and colorings, and clean food displays.

Attractive food packaging made of cans such as formula milk products is the result of industrial processing that has influenced the opinion of poor families in assessing the quality of the food. Poor families believe that attractive packaging must contain high nutritional value. Industrially processed foods with attractive packaging contain preservatives to last for a long time.

The way nutrition capitalism works in the form of framing the value of nutritional content often adjusts people's perceptions of the nutritional content of certain foods. Many industrial food products juxtapose nutritional content with foods that are of interest to the public, such as eggs, milk, tempeh, and tofu. All of these strategies lead to the accumulation of profits which is indeed the main motivation of the capitalists.

The meaning of nutritional content spreads rapidly in the memories and perceptions of the poor following the advent of an online shopping system. Quick access to information about food is slowly shaping the character of practicality in choosing and consuming industrially processed foods. The behavior of self-processing foodstuffs, which is a 
habitus for poor families, is degraded as a result of the construction of information presented in the online shopping system.

\section{Advertisement}

Below are excerpts from the core interview about advertising:

"We don't know if it's high in nutritional value or what. No. It's just like on TV, if that's good. (Bau, Barombong, 2019).

"It's like he said people, fish. Salmon is high in Omega 3 but right here there is no salmon, only milkfish have to be given, at least there is something like that". (Lina, Maccini Sombala, 2019).

"If Dancow has docosahexaenoic acid (DHA). It's rare, it just means that the price is relatively cheap, it's still affordable, it just fits my son too". (Kaminang, Mangasa, 2019).

"Well, some are yes, some are not. Like for example noodles. noodles. instant noodles. If it's instant noodles, how about. how about the advertisement on TV. It's like, wow, it's so delicious, so nutritious. But if you eat it. just like normal. that's how it is. But that's what people do so that we're interested in buying. that's how it is". (Sarifa, Balang Baru, 2019).

"Yes, because before I saw Dancow's ad, eee. my son is not Dancow, he drinks. From the age of 0 months to 6 months, uh to 1 year, he doesn't drink Dancow. Bebelac, but because that was the day there was counselling at the Community Health Center. It was suggested that it was like Dancow. just the advertisements. Anyway, all of them, advertised on TV, that's Dancow. Incidentally also matched with Radit (Respondent's child). That's why I continue to give it". (Memang, Jongaya, 2019).

Advertising is one of the triggers for changes in consumption patterns in the poor in Makassar, including formula milk advertisements that are presented from various media such as TV media. The capitalization of nutrients in formula milk, such as Dancow, which contains the nutrient DHA which is high enough to shape children's brain development, is easily accessible to informants.

Based on exposure to advertisements carried out by formula milk producers in marketing their products, informants gave a better assessment of formula milk with the Chilkid brand compared to other brands. However, the informant was unable to provide Chilkid milk to his child because his economic capacity was not sufficient to obtain the intended formula milk.

People no longer have rational awareness in deciding to buy. Anyway, what is shown in the media is what is considered the ultimate truth. All elements of public cognition about the nutritional content of food only move around the information presented in media such as television.

Advertising systematically constructs knowledge and tastes which ultimately leads consumers to only buy products as directed by advertising messages. For the informants, nutritional content such as omega-3 is only found in salmon or types of fish that have similarities to salmon. Omega-3 content can be obtained from various food ingredients found in everyday life.

The display of industrially processed food advertisements on social media is excessive when compared to the real thing. Irrationality is a sign of language that is communicated in the informant's statement. There is a rational awareness about advertisements that are not by reality but are still consumed because of the sensation of attraction. In addition to the sensational packaging of products designed in advertisements, exposure to advertisements in the media with high frequency is quite effective in instilling a concept of understanding in consumers. Understanding the concept that has been deeply embedded in consumers creates tastes, motivations, intentions, beliefs, and desires to position the product as a need.

The process of adopting consumption behavior eventually leads to permanent behavior and succeeds in replacing the old behavior of people who usually still use local food and drinks to fulfill their needs. The reason for the availability of scarce local products is probably due to lack of motivation to search because the advertised product is very easy to obtain or obtain. Attitudes and practical actions of consumers in buying have been successfully constructed effectively by advertising.

\section{Discussion}

Knowledge is a primary factor of nutritional disorders in addition to poverty and food availability. Almatsier (2004) says that nutritional disorders are caused by primary and secondary factors. The primary factor is when a person's food composition is wrong in quantity and or quality caused by a lack of food supply, poor food distribution, poverty, ignorance, wrong eating habits, and so on. Secondary factors include all factors that cause nutrients not to reach the body's cells after food is consumed [8]. Knowledge can trigger consumption behavior only if it is supported by a strong attitude or motivation. Behavior is determined by the mother's motivation even in some cases even though the mother's knowledge is good but not supported by good motivation; the mother's behavior will not develop positively [9]. 
Behavior Eating patterns that are influenced by knowledge and attitudes appear in a variety of information that provides an overview of the types and amounts of foodstuffs eaten daily by one person and is a characteristic for a particular community group. This eating pattern is influenced by several things, including pleasure habits, culture, religion, economic level, natural environment, and so on. Since time immemorial, food in addition to strength/growth fulfills hunger and appetite, also has a place as a symbol, namely a symbol of prosperity, power, peace, and friendship. All of the above factors mix to form a compact ingredient that can be called consumption patterns [10].

The main knowledge that is often used as a central meaning in consumer behavior is the content of nutrients. Morley (1997) and Harper et al. (2009) argued that food provides the body's chemical elements known as nutrients. In turn, these nutrients provide energy for the body, regulate processes in the body and make growth smooth and repair body tissues [11], [12]. We still often encounter various habits related to certain dietary restrictions, for example, the prohibition against children to eat eggs, fish or shrimp is only based on a habit that has no basis and is only inherited from generation to generation. Habits, myths, superstitions or beliefs/customs of certain communities that are not correct in feeding will be very detrimental to children. According to Foster et al. (2006), anthropologists view eating habits as a complex of cooking activities, problems of difficulty and difficulty, folk wisdom, beliefs, taboos, and superstitions related to production, preparation, and consumption of food [13].

Lack of knowledge of mothers about nutrition makes mothers prefer to follow beliefs, myths, and superstitions that develop in people's lives. Hence, it does not use rational considerations in calculating the type and content of the food chosen for consumption by the toddler. According to Santoso and Ranti (2004) to be able to compile an adequate menu, one needs to know food ingredients and nutrients, one's nutritional needs and knowledge of dishes and their processing [10]. Usually, the menu is prepared by the mother. Food consumption affects the nutritional status of children under five. The condition of good nutritional status can be achieved if the body gets sufficient nutrients. Lack of knowledge of maternal nutrition will affect the selection and provision of food in the family, especially for toddlers so that it can affect the toddler's diet (Figure 1).

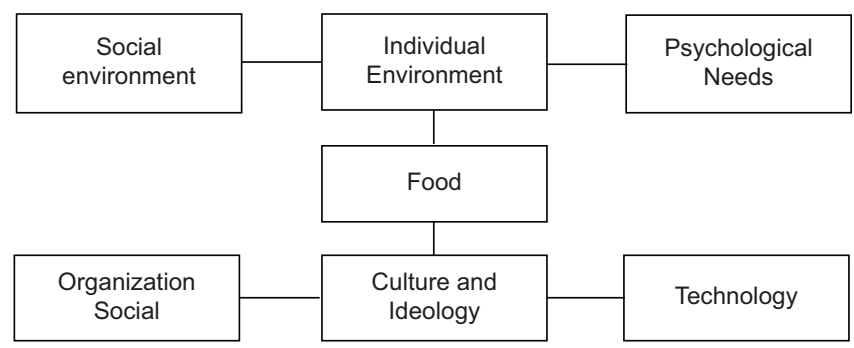

Figure 1: Ecological models in nutritional anthropology

Source: Jerome 1980. "An Ecological Approach to Nutritional Anthropology". USA: Redgrave Publishing Company.
This study influenced by an ecological model in nutritional anthropology developed by Jerome (1980) [14]. An analysis that places the position of food as a biological need is central to a model influenced by other complementary factors. These factors include the social environment, physical environment, social organization, technology, culture, and ideology. Where the picture of this ecological model explains that food as a biological need is influenced by these factors.

Social environmental factors that influence malnutrition are the environment that shapes food habits and beliefs about food that exists in society. Such as the existence of certain views about food, the existence of values or understandings about the concept of food, taboos, and the eating culture of the community that prioritizes taste, taste, and enjoyment in choosing and determining food.

Ironically, there is an ambivalent awareness, namely rational awareness about knowledge of flavoring foods that are less healthy and practical awareness about flavoring as a product line for profit accumulation. This ambivalence awareness can be categorized as a false awareness that afflicts mothers of urban poor families in perceiving, knowing, and choosing nutritious food for their families.

Food and appetite are something that cannot be separated as a social institution that fulfills many functions and can only be understood in the context of a comprehensive culture; therefore, culture plays a role in determining food, meaning whether it is appropriate or not to be eaten [13]. Many people still show that people's lives are still strongly influenced by culture and ideology. Such as eating culture, eating priorities, consumption and distribution patterns, beliefs, myths, and superstitions that exist in people's daily lives. In choosing and determining food, people are still influenced by culture and ideology that has been passed down from generation to generation.

Food contains social, cultural and psychological properties and meanings. How the socio-cultural and psychological dimensions of food relate to the problem of adequate nutrition, especially in traditional societies. The meaning of food for the community is as an expression of social ties, food as an expression of group solidarity, and food symbolism in language [13]. This symbolic meaning was then degraded along with the rampant characteristics of capitalization of nutrients that plagued the urban poor. They are dragged into consumptive behavior.

Consumptive behavior is an individual act as a consumer to buy, use or consume goods or services excessively, irrationally, causing waste, and only prioritizing desires or pleasures without considering the needs or benefits of these goods or services, even just to gain social recognition, following fashion or personal satisfaction. Consumers in buying a product are no 
longer just to meet needs, but also the desire to satisfy tastes and pleasures.

The behavior of consuming nutritious food should be a top priority in every family. Without eating foods that contain complete nutrition, a person cannot live a healthy life, both physically and spiritually. As the definition of nutrition quoted from Supariasa et al. (2002) states that nutrition is a process of organisms using food that is consumed normally through the process of digestion, absorption, transportation, storage, metabolism and the release of substances that are not used to maintain life, normal growth and function of organs, as well as energy production [15].

Fulfilling adequate nutritional intake and maintaining nutritional conditions are very important for the needs of the health condition of the human body because nutrition has a role as a source of energy and can produce energy for the human body. By eating foods that have sufficient nutritional levels, it is very good for the health of the body. According to Santoso and Ranti (2004) through food, humans get food substances or nutrients which are basic human needs to live, grow, and develop [10].

The food consumption behavior of the poor does not consider the nutritional balance. Food choices sometimes only highlight certain nutritional content, including the type of food consumed in monotonous types and levels. Therefore, the community experiences malnutrition with the main nutritional deficiency condition. What stand out is lack of calories, lack of protein and lack of Vitamin A, iodine, iron, other vitamins, and minerals [10].

The environment also contributes to socially constructing consumption behavior. In social interaction, imitation of behavior begins personally, from individual to individual, and then mushroomed in groups, called lifestyle. A Professor of Sociology at Durham University, Cheney (2004) examines lifestyle issues more comprehensively and is based on various perspectives. According to him, lifestyle should be seen as an individual effort in forming self-identity in social interaction [16]. According to Baudrillard, identity is a self-concept that arises because of the determining factors that arise from something inherent or carried out by individuals solely so that they can be recognized and accepted by society as an individual who is imaged [17]. The concept of identity can also be seen and compared with Sartre's thoughts in his book "Philosophy of Existentialism", on the concept of "being" as a form of personal existentialism, because something that exists is ourselves by highlighting the identity we have [18].

In society, each group has its pattern of obtaining, using, and appraising food which will be a cultural feature of each group. In general, people give certain definitions of the meaning of food such as there are types of food to sell and others to eat at home, there are types of food for the rich and some for the poor, Some are for parties, for women, children, the elderly, and others. Sick people, there are types of food that are not allowed for certain people including based on gender [10], [19], [20].

Trust is often or obtained based on belief and without any prior proof, usually, this trust is obtained from parents, grandparents and who are considered more understanding [21]. Myths are false information but are considered true that have been believed, circulated and popular in society. Myths develop quickly in society because they are interesting to discuss and people find it difficult to get correct information. As a result, many myths and misunderstandings are circulating in society.

The problem of food is not just a question of medical nutritional content, but a cultural issue, namely, beliefs about food and food habits. Food beliefs and food habits are not easy to change. Because food beliefs (some call it "food ideology") are the core of a culture that is difficult to change [22]. Food determines the identity of the group so that the character and culture of the group can be identified from the type of food [16]. The meaning of local culture is reinterpreted by the industry into a universal meaning through advertising techniques.

Advertising a product is to influence the attitude of the audience, in this case of course the attitude of the consumer [23]. Seeing the purpose of advertising is to influence the attitude of a consumer, and then the main purpose of influencing consumer attitudes is to make consumers make a purchase. According to Amirullah in Khusnaeni et al. (2017) decision-making is a process of assessing and selecting from various alternatives by certain interests by determining an option that is considered the most profitable. Various considerations are made by consumers before making a purchase. Attitude is a comprehensive evaluation of a product by assessing the product as favorable or unfavorable. Consumers will make purchasing decisions after determining attitudes toward a product. A positive attitude towards a product will lead consumers to buy the product, but on the contrary, a negative attitude will prevent consumers from buying the product. The power of advertising in constructing consumers influences the decision to buy the product in various ways [24].

This study further understands the sociocultural contribution of malnutrition in children under five in poor families, seen from the prevention which cannot be completed through medical and health approaches because these approaches only look at the problem of malnutrition from the aspect of human biology. So in the effort to overcome and prevent malnutrition problems require a socio-cultural approach to the community because if the culture in the community is positive in terms of health, it will support the success of the health world in dealing with nutritional problems. Koentjaraningrat (1984) quoted by Santoso and Ranti (2004) states that the eating habits 
of individuals, families and communities are influenced by behavior, social environment, population structure, economic environment, and ecological environment, soil conditions, climate, biological environment, farming systems, market system, and factors of food availability [10].

\section{Conclusions}

The occurrence of malnutrition in the poor in Makassar City is caused by the wrong knowledge of the community in understanding nutritious food. Meanwhile, children's tastes are formed based on environmental influences constructed by industrial processed food. The capitalism framework in marginalizing the poor in fulfilling nutritional needs operates through the presence of processed food and beverage industry, exposure to food and beverage product advertisements, the emergence of online food ordering startup technology, the number of easily accessible franchise store outlets, and the construction of internal parties in the daily life of a poor family or imitation of their lifestyle. To raise a rational awareness about foods and beverages that have a balanced nutritional content, education is needed on the rational knowledge of poor families regarding the nutritional content of certain foods and beverages.

\section{Acknowledgments}

The author would like to thank nine families who participated in this study.

\section{References}

1. Moniharapon E, Sumanvan U, Khomsan A, Sukandar D Analisis klaim iklan dan label pada produk pangan. Media Gizi Dan Kel. 1999;23(2):36-45.

2. Hidayat IK, Sumarwan U, Yuliati LN. Persepsi dan sikap ibu terhadap klaim gizi dalam iklan susu formula lanjutan anak usia prasekolah dan hubungannya dengan keputusan pembelian. J IImu Kel Konsum. 2009;2(1):77-85. https://doi.org/10.24156/ jikk.2009.2.1.77

3. Sabriyan AN. Hubungan Antara Persepsi Terhadap Iklan Susu Formula Di Televisi Dan Pengetahuan Gizi lbu Dengan Tindakan Ibu Dalam Pemberian Susu Formula. Yogyakarta: Progres Studies Pendidik Venkat Boga, Fakultas Teknik Universitas Negeri; 2013. https://doi.org/10.19184/ikesma.v13i1.7027

4. Kementrian Kesehatan Republik Indonesia. Laporan; Riset
Kesehatan Dasar (RISKESDAS) 2013. Jakarta: Badan Penelitian Dan Pengembangan Kesehatan, Kementrian Kesehatan Republik Indonesia; 2013. https://doi.org/10.6066/ jtip.2013.24.2.121

5. Kementrian Kesehatan Republik Indonesia. Laporan; Riset Kesehatan Dasar (RISKESDAS) 2007. Jakarta: Badan Penelitian Dan Pengembangan Kesehatan, Kementrian Kesehatan Republik Indonesia; 2008. https://doi.org/10.6066/ jtip.2013.24.2.121

6. Kementrian Kesehatan Republik Indonesia. Laporan; Rise Kesehatan Dasar (RISKESDAS) 2010. Jakarta: Badan Penelitian Dan Pengembangan Kesehatan, Kementrian Kesehatan Republik Indonesia; 2010. https://doi.org/10.6066/ jtip.2013.24.2.121

7. Agustang A. Filosofi Research. Makassar: Dalam Upaya Pengembangan IImu; 2011. https://doi.org/10.31219/osf. io/9n6za

8. Almatsier S. Penuntun Diet. Jakarta: Jakarta PT Gramedia Pustaka Utama; 2004.

9. Adam A, Palutturi S. The effect of extension methods on knowledge and attitude of young women about "Sadari" at immim high school of Pangkep district. Indian J Public Heal Res Dev. 2019;10(3):539. https://doi. org/10.5958/0976-5506.2019.00554.0

10. Santoso S, Ranti AL. Kesehatan Dan Gizi. Jakarta: Rineka Cipta; 2004. p. 165-176.

11. Morley D. Theoretical orthodoxies: Textualism, constructivism and the "New Ethnography" in cultural studies. Cult Stud Quest. 1997:121-37. https://doi.org/10.4135/9781446278994.n8

12. Harper LJ, Deaton BJ, Driskel JA, Suhardjo. Pangan, Gizi dan Pertanian. Indonesia: Universitas Indonesia; 2009.

13. Foster GM, Anderson BG, Suryadarma PP, Swasono MF Antropologi Kesehatan. Indonesia: Penerbit Universitas Indonesia; 2006.

14. Jerome NW. An ecological approach to nutritional anthropology. Nutr Anthropol. 1980;67(6):13-46.

15. Supariasa ID, Bakri B, Fajar I. Penilaian Status Gizi. Vol. 5. Jakarta: EGC; 2002

16. Cheney D. Lifestyles; Sebuah Pengantar Komprehensif, Terj, Nuraeni. Yogyakarta: Jala-Sutra; 2004.

17. Lubis AY. Postmodernisme: Teori Dan Metode. Jakarta: Jakarta Rajawali Pers; 2014

18. Sartre JP. Filsafat Eksistensialisme. Yogyakarta: Kanisius; 2011.

19. Nurdin BV. Budaya Makan Pada Ibu Hamil Penderita Gizi Buruk. Lampung: Studi Tentang Prioritas Makanan Dalam Perspektif Gender di Bandar Lampung; 2010.

20. Napu A. Penerapan ilmu gizi berbasis makanan khas daerah menyehatkan dan melestarikan Budaya Bangsa: Pembelajaran tentang Gizi, kesehatan dan Kepemilikan Budaya. J IIm Agropolitan. 2010;3(2):361-7. https://doi.org/10.25182/ jgp.2006.1.1.29-35

21. Notoatmodjo S. Pendidikan Dan Perilaku Kesehatan. Jakarta: Rineka Cipta; 2003.

22. Linton RE. The Science of Man in the World Crisis. United States: American Psychological Association; 1945.

23. Jefkins F. Periklanan (Advertising). Jakarta: Airlangga; 1996.

24. Khusnaeni NL, Yulianto E, Sunarti S. Pengaruh iklan terhadap sikap konsumen serta dampaknya pada keputusan pembelian (survei pada mahasiswa S1 Universitas Brawijaya malang pengguna kartu seluler telkomsel 4G LTE yang pernah melihat iklan telkomsel 4G LTE Versi "Nixia Gamer"). J Adm Bisnis. 2017;47(2):49-56. https://doi.org/10.51826/fokus.v16i1.146 